\title{
Strategic Government Initiatives to Promote Diffusion of Online Retailing in Saudi Arabia
}

\author{
Rayed AlGhamdi \\ ICT School \\ Griffith University \\ Brisbane, Australia \\ r.alghamdi@griffith.edu.au
}

\author{
Steve Drew \\ ICT School \\ Griffith University \\ Brisbane, Australia \\ s.drew@griffith.edu.au
}

\author{
Mohammed Alshehri \\ ICT School \\ Griffith University \\ Brisbane, Australia \\ m.alshehri2@griffith.edu.au
}

\begin{abstract}
This paper presents findings from a study of factors affecting the rate of diffusion and adoption of online retailing in Saudi Arabia. In general, Saudi retailers have not responded actively to the global growth of online retailing. Accordingly, this research was conducted to find the key factors involved in this phenomenon. A major finding presented here, is that both buyers and sellers emphasize the need for government involvement to support and promote development of online commerce. Particularly, it indicates the need for strategic government initiatives to provide regulation, legislation, education, and trusted infrastructure for secure payment and delivery. Saudi Arabia presents a unique cultural, technological and political context for the development of e-commerce. We highlight the particular motivators and potential benefits of Saudi government involvement in e-commerce development. A new model for formulating roles and strategic government initiatives to support the successful diffusion of online retailing in KSA is presented and discussed. This will be of interest to any following the development of e-commerce and the information economy in the Arab nations.
\end{abstract}

Keywords- online retail; Saudi Arabia; e-commerce development; government roles

\section{INTRODUCTION}

The number of commercial organizations in the world that tend to apply electronic commerce systems is on the rise. In the near future, this trend will become not only a tool to simply increase income, but without doubt will be considered an essential means for competition [1]. While developed nations have become familiar with e-commerce, it is still considered an innovation in the Saudi context. Reference [2] defined an innovation as an idea, practice or object that is perceived as new by an individual or other unit of adoption. Despite the fact that Saudi Arabia has the largest and fastest growth of ICT marketplaces in the Arab region [3-5], ecommerce activities are not progressing at the same speed [69]. Currently only a tiny number of Saudi commercial organizations, mostly medium and large companies from the manufacturing sector and mainly Business to Business (B2B), are involved in e-commerce implementation [9].

Separate studies have been conducted to determine the key issues influencing online retailing sales and purchases for both retailers and customers in Saudi Arabia. These studies were conducted using mixed qualitative and quantitative approaches through which several key issues have been indicated. Among these issues, which both retailers and customers emphasized, is the lack of lack of clear regulations and legislation and the need of government supervision and support [10-14]. Reference [15] indicated that the government initiative to support e-commerce growth in Saudi Arabia is currently a missing key factor.

In the following sections we provide a summary review of literature regarding the nature of retail business in Saudi Arabia; and the current state of the nation's online retail sector development. A synthesis of findings from different strands of our research is presented followed by a description of the research methodology used. Insights into the Saudi context highlight the potential that government interventions to facilitate the diffusion of e-commerce may have. A model, based on this research, is presented that indicates the strategic initiatives that the Saudi government might implement for best effect.

\section{LITERATURE REVIEW}

In this section, we look at traditional and online retailing businesses in Saudi Arabia. Government support for ecommerce development and online retailing in other countries is also reviewed.

\section{A. Retail Business in Saudi Arabia}

The average of annual population growth rate in the Kingdom of Saudi Arabia has reached 3\% over the past 10 years. This seems to be playing a role in making Saudi Arabia one of the most dynamic retail markets and most notably in the Middle East [16]. "With an estimated population of 24.9 million and a per capita GDP of US\$24,581 in 2008, Saudi Arabia is the largest and one of the richest retail markets in the Middle East" [17].

Over the last decade, the retail business in Saudi Arabia has seen significant growth. International retailers have entered the local market and the number of local retailers has expanded [18]. In 2010, Saudi Arabia ranked number 4 in the global retail development index [18]. Currently there are 1.4 million employee in retailing sector in Saudi Arabia and expected to reach 2 million within 10 years [19]. The current percentage of Saudi employees in the retail sector is almost $17 \%$ (or 270 thousand) with the remaining $83 \%$ made up of foreign workers [19]. This represents a significant market place. 
There are no available official records indicating the size of the retail business in Saudi Arabia. However some sources estimated the size of the retail market in Saudi Arabia is greater than KSR160 billion (US\$1= KSR3.75) dominated by small and medium size companies accounting for more than $85 \%$ of market share $[20,21]$. According to The Saudi Ministry for Municipal and Rural Affairs, the number of retailers in Saudi Arabia reached 242 thousand; 54 thousand of them are licensed for grocery [20]. The retail sector in the Saudi market is fragmented and dominated by sales in individual stores, despite the emergence of a number of large retail chains in recent years [16].

\section{B. Online retail in Saudi Arabia}

In Saudi Arabia, so far, the effort towards e-commerce development has not reached the originally stated aspirations of the Ministry of Commerce. Neither does it meet what it sees as the world's expectations of a country of the level of importance and weight in the global economy as Saudi Arabia. Saudi Ministry of Commerce has appointed a committee for e-commerce to prepare a general framework for a plan to apply e-commerce systems in Saudi Arabia. This framework includes the improvement of various factors involved with e-commerce transactions (e.g. IT infrastructure, payment systems, security needs, legislations and regulations, delivery systems etc). The plan also includes the development of e-commerce education and training [3]. However, this information was gained from the first publication booklet of Saudi Ministry of Commerce in regards to e-commerce written in 2001. No further information has been published to either the Saudi Ministry of Commerce website or its documents that provide further details about this committee and its current role in ecommerce development in the country. Official government information on e-commerce in Saudi Arabia is lamentably poor. Since 2006, the responsibility of e-commerce has transferred from the Ministry of Commerce to the Ministry of Communications and Information Technology. This information was gained from an exploratory phone call made in December 2010 to the Saudi Ministry of Commerce. It was explained that the Ministry of ICT in Saudi Arabia is still in its early stages of studying e-commerce. At the time of writing, a survey was conducted by the Ministry of ICT into e-commerce in Saudi Arabia and a report was published in May/June 2011. The report briefly restated that ecommerce in Saudi Arabia is still in its early stages. "While $30 \%$ of businesses and $13 \%$ of government organizations buy online, only $8 \%$ of the businesses sell online. In particular, "clicks and mortar" business is still in its infancy, as most Saudi retail chains have yet to establish an online channel. On the consumer side, there is as yet little adoption of e-commerce, although surveys show that more individuals plan to try it in the future" [9].

Firms in Saudi Arabia seem not to be following the developed countries' rapid progress towards global ecommerce. In contrast, online shoppers in Saudi Arabia are increasing with improved access to technology and communications infrastructure. The Arab Advisory Group carried out an extensive survey in mid-2006, targeting Internet users in four Arab countries (Saudi Arabia, UAE,
Kuwait and Lebanon). The survey covered Internet usage and, e-commerce activities in these countries. While UAE ranked first in the rate of annual spending on e-commerce per capita, Saudi Arabia ranked first in the overall money spent on e-commerce activities such as buying from global retailers, e.g. Amazon, eBay, Dell etc, and including airlines tickets and hotels online booking. As for the prevalence of ecommerce activities among the population, UAE ranked first at $25.1 \%$, Saudi Arabia second at $14.3 \%$, Kuwait third at $10.7 \%$ and Lebanon last at $1.6 \%$ [22]. A recent survey of Saudi Arabia's 11.4 million Internet users (representing 41\% of population) found that around 3.1 million Saudis have purchased online. Airline tickets and hotels bookings take the largest percentage of these purchases [17] and [22].

Some studies have been conducted to investigate the challenges of e-commerce in Saudi Arabia. These challenges involve the absence of clear e-commerce regulations, legislation, and rules [23, 26]. Although Saudi Arabia contributes to the efforts of UNCITRAL (United Nations Commission into International Trade Laws) [3], there is a need to have major development in terms of domestic ecommerce regulations, legislations and rules to protect the rights of all parties involved in e-commerce transactions [6, 23, 26]. Other challenges involve the domestic mailing system [5]. Before Saudi Post was established in 2005, individuals had no home addresses [24]; therefore, to receive mail, individuals had to subscribe to have a mailbox in the post office [5].

This study draws together findings from research stages that have been recently conducted and published in four earlier papers. In these stages we determine key issues, and their interrelationships, that influence online retailing growth for both retailers and customers in Saudi Arabia. Several key issues have been indicated as illustrated in Tablel and Table 2 below [10-14].

Table1: Overview of the inhibitors and enablers for customers to purchase online from retailers in Saudi Arabia

\begin{tabular}{|c|c|c|}
\hline Rank & Inhibitors to Customers & Enablers for Customers \\
\hline 1 & Lack of physical inspection & Bricks to support clicks \\
\hline 2 & Lack of regulations & Government supervision \\
\hline 3 & Privacy concerns & Competitive prices \\
\hline 4 & Lack of experience & $\begin{array}{l}\text { Trustworthy and secure online } \\
\text { payment options }\end{array}$ \\
\hline 5 & Trust concerns & Owning house mailbox \\
\hline 6 & $\begin{array}{l}\text { Lack of leading retailers offer } \\
\text { online sales }\end{array}$ & $\begin{array}{l}\text { Well-designed retailer websites } \\
\text { (photos of products) }\end{array}$ \\
\hline 7 & $\begin{array}{l}\text { Do not own a home mailbox/ } \\
\text { home address }\end{array}$ & $\begin{array}{c}\text { Easy access and fast Internet } \\
\text { speed }\end{array}$ \\
\hline 8 & $\begin{array}{l}\text { Uncomfortable paying online } \\
\text { using credit cards }\end{array}$ & Provision educational programs \\
\hline 9 & $\begin{array}{l}\text { Lack of English language } \\
\text { understanding }\end{array}$ & $\begin{array}{l}\text { Local banks make owning } \\
\text { credit cards easier }\end{array}$ \\
\hline 10 & No/slow access to Internet & Others \\
\hline 11 & Others & \\
\hline
\end{tabular}

Table2: Overview of the inhibitors and enablers for Retailers in Saudi Arabia to adopt e-commerce

\begin{tabular}{|c|c|c|}
\hline Rank & Inhibitors to Retailers & Enablers for Retailers \\
\hline $\mathbf{1}$ & $\begin{array}{c}\text { Current habits of people in KSA } \\
\text { does not suit online transactions }\end{array}$ & $\begin{array}{c}\text { Providing trustworthy and } \\
\text { secure online payment options }\end{array}$ \\
$\mathbf{2}$ & $\begin{array}{c}\text { Lack of clear legislations and } \\
\text { rules of e-commerce in KSA }\end{array}$ & $\begin{array}{c}\text { Government support and } \\
\text { assistance for e-commerce }\end{array}$ \\
\hline
\end{tabular}




\begin{tabular}{|c|c|c|}
\hline 3 & Lack of e-commerce experience & $\begin{array}{l}\text { Develop strong ICT } \\
\text { Infrastructure }\end{array}$ \\
\hline 4 & $\begin{array}{l}\text { Products are not suitable to be } \\
\text { sold online }\end{array}$ & $\begin{array}{l}\text { Educational programs for people } \\
\text { and building the awareness of e- } \\
\text { commerce in the country }\end{array}$ \\
\hline 5 & Poor ICT infrastructure & $\begin{array}{c}\text { Provision of sample e-commerce } \\
\text { software for trialling }\end{array}$ \\
\hline 6 & $\begin{array}{l}\text { Lack of online payment options } \\
\text { in KSA to help build the trust of } \\
\text { customers }\end{array}$ & Others \\
\hline 7 & Resistance to change & \\
\hline 8 & Others & \\
\hline 9 & $\begin{array}{c}\text { Not trusting online sales } \\
\text { activities }\end{array}$ & \\
\hline 10 & Cannot offer delivery service & \\
\hline 11 & Setup cost & \\
\hline 12 & Not be profitable/ useful for us & \\
\hline 13 & $\begin{array}{l}\text { Cannot offer a competitive } \\
\text { advantage over competitors }\end{array}$ & \\
\hline
\end{tabular}

The most interesting finding in Tables 1 and 2 is that both retailers and customers emphasized the lack of lack of clear regulations and legislation and the need for government supervision and support. Convincingly, this issue is ranked uniformly at number two in this study. It indicates that any current government efforts to support e-commerce in the country are having insufficient impact to positively influence retailers and customers. This confirms what has been found in the literature stating that the government efforts supporting e-commerce in Saudi Arabia are insufficient [23, 26].

Retailers with previous online sales experience also provide clear and practical indications as to the top enabling factors. These are developing online payment options, enhancing ICT infrastructure and government regulations and support [13]. From customers' perspective, trust in Saudi e-retailers (or the lack of it) is probably the most important factor affecting current and potential Saudi customers. From this, it is reasonable to draw the implication that the government can play, if it so wishes, a key role in regulating, supervising, and facilitating e-retail in Saudi Arabia [14]. The critical question, then, becomes whether there are valid justifications for the government to take such an interventionist role in normal commerce, as opposed to the cases of e-government and e-learning which involve public services or "social" goods. Such a question must be left to future research. It certainly appears that if e-commerce is to develop in the Saudi context then strategic government intervention will accelerate e-commerce development.

\section{RESEARCH METHODOLOGY OVERVIEW}

This project studying the diffusion of online retail in Saudi Arabia is built on the combination of qualitative and quantitative approaches. Qualitative study conducted first for exploration purpose and followed by quantitative approach based on qualitative findings for testing purpose. This type of approach is called exploratory mixed methods design [25] which is done "to explore a phenomenon, and then [collect] quantitative data to explain relationships found in the qualitative results" [25]. The mixed methods approach helps to provide an in-depth investigation of the research problem [26].

The qualitative stage involved 16 interviews with retailers in Saudi Arabia from different sizes and businesses, and 16 interviews with customers (males and females) in Saudi Arabia. This stage followed by quantitative step based on the qualitative findings to test in a wider sample. The retailers' sample size was 148 (representing different businesses, sizes, and familiarity with using Internet and online sales). The sample size of the customers has reached 412 at this stage and will be extended to around 700 by the end of the study.

\section{POTENTIAL IMPACT OF SAUdi GOVERNMENT SUPPORT FOR THE DIFFUSION OF ONLINE RETAILING}

Basically, Saudi Arabia will benefit from taking an active role in developing e-commerce in the country as other countries have benefitted. In the new global economy, ecommerce has become a significant tool for competition. Ecommerce has also brought a range of benefits to its users. In general, e-commerce offers increased convenience and access to a marketplace that is not contained by national borders but also, often national rules. It has the potential to cut down costs of goods and service. It can improve a business' competitive position, offering larger marketplace, faster and easier services to customers, help to reduces operational and administrative costs, and meets customers' demand for the service [7]. "The manifold benefits of eCommerce can be summarized as related to expanding market reach in allowing for the overcoming of geographical limitations, increased availability $(24 \times 7)$, eliminating intermediaries, lowering transaction cost for buyer and seller, decreasing administrative, marketing and logistics costs, providing a competitive environment to improve the quality of goods and services, increase the convenience of obtaining goods and services, and allowing for a provision of more customized offering as well as a new way of managing relationships. Specific advantages can be clustered around cost, operational, market reach, innovation or other benefits." [27] Online shopping is not only useful for retailers but also for customers. Customers gain advantages through online shopping in terms of time and effort savings, variety of products available for them online, and easy movement from one e-store to another comparing quality and prices to find out the best offers without leaving their home of office. Online shopping gives convenience to online shoppers [1].

There are particular benefits to increasing e-commerce that become apparent when considering the Saudi retail context. Support for e-commerce growth in the country should help to minimizing the increasing number of neighborhood stores in the streets. Neighbourhood stores are almost in each main street in Saudi main cities. These types of shops are co-located with residences in residential/business buildings. A typical retail street scene is depicted in Figure 1.

It will add an alternative to people want to avoid going out for shopping which helps to decrease the traffic jams in the Saudi main cities' streets. It also offers good opportunity for women, who are not allowed to drive cars in Saudi 
Arabia, to shop from home without having concern of transportation when they need to do shopping. Online retailing will offer also advantage for residents of other Saudi cities other than the main cities. In holidays most Saudis travel to the main cities for the purpose of shopping. Eretailers can advantage those people who live in non-main cities allowing them to purchase goods without the hardship of travel when they offer online sales options. Retailers also gain advantage by maximizing their marketplace not only in Saudi Arabia but also globally if they wish.



Figure 1: Baqalas (neighbourhood stores) along Jeddah Road

Supporting the online retail market in Saudi Arabia to expand helps to reduce the growth in the number of traditional retail shops. Reducing the number of traditional retail shops helps in two ways: (1) reduces the number of foreign workers that transfer huge amount of money to their countries which will help the local economy; and, (2) increase the opportunities for Saudis to work in retail sector. There is a negative perception among Saudis about working in retail. They feel these types of jobs are mainly for foreigners. Mostly they prefer government and office jobs: "social norms, customs and traditions in circulation among the people standing barrier to any idea to open a project, for example, grocery store, says: Saudi does not work in the grocery store" [20]. Nowadays, this negative perception is changing but slowly. Online retailing helps to create jobs for IT skilled people. Working in marketing, selling products, and providing customer services while sitting in an office behind computer will help to attract more Saudis and especially females as the environment will be more convenient for them.

Unemployment in Saudi Arabia reached $10.5 \%$ of the population aged 15 years and above in 2009 . The current trend appears to be a yearly increase of $0.5 \%$. When it comes to gender, $28.4 \%$ of females were unemployed in 2009 while only $6.9 \%$ of males [28]. According to the latest statistics from Saudi Central Department of Statistics \& Information [28], the number of foreign labourers in Saudi Arabia reached 8,429,401 million. Their proportion to the population of Saudi Arabia is almost 31\% [28]. 23\% of them work in the retail and wholesale sectors [29], and their proportion in the retail sector to Saudis reaches 83\% [19]. In 2007 , the total amount of money sent overseas by foreign labours reached KSR60 billion [29]. Saudis also find it difficult to compete with foreigners for the traditional retail store jobs. Foreigners come to Saudi Arabia mainly to work and most of them have left their families in their home countries because only those who work in high position jobs (e.g. doctors, engineers, academics, teachers etc) are allowed to bring their families with them. For this reason, most workers work day and night and share accommodation to benefit from reduced living costs. On the other hand, Saudis have their families to support locally and they have a lot of related commitments. For example, a Saudi has a retail shop. He works from 8 am-12noon, takes rest time to bring his kids from school, have lunch, and comeback to his/her work around $4 \mathrm{pm}$. He has to close at 8 or $9 \mathrm{pm}$ to go home to lead family commitments. In contrast, nothing distracts foreigners' emphasis on their work. They are ready to work in a similar shop from $7 \mathrm{am}-12 \mathrm{pm}$ without stop which makes them highly employable.

Support for e-commerce retail was highly indicated by Saudi retailers and customers in the findings of previous studies [10-14]. Retailers with previous online sale experience also provide clear and practical indications as to the top enabling factors. These are developing online payment options, enhancing ICT infrastructure and government regulations and support [13]. From customers' perspective, trust in Saudi e-retailers (or the lack of it) is probably the most important factor affecting current and potential Saudi customers. From this, it is reasonable to draw the implication that the government can play, if it so wishes, a key role in regulating, supervising, and facilitating e-retail in Saudi Arabia [14].

\section{DEVEloping STRATEGIC INITIATIVES FOR SAUDI GOVERNMENT INTERVENTION}

So far, the outcomes achieved in e-commerce development in Saudi Arabia are not reaching the expectations of a country with the importance and weight in the global economy like Saudi Arabia. Governments do have an important role to play in e-commerce. Building the trust in the digital economy should be priority number one. As discussed in earlier section, consumers and retailers in Saudi Arabia seem not to trust this type of business though not because of ignorance but because of the absence of a clear regulation system. As mentioned earlier, although Saudi Arabia contributes to the efforts of UNCITRAL, e-commerce regulations, legislations and rules to protect the rights of all parties involved in e-commerce transactions remain unaddressed.

Figure 2 illustrates a proposed model showing what might be implemented or supervised by the government in order to promote an attractive e-commerce environment in Saudi Arabia. The model has five important elements as summarized from the previous research stage findings. These elements involve: introducing e-commerce law, offering trustworthy and secure online payment options, introducing e-commerce educational programs, enhancing the national delivery system, and developing strong ICT infrastructure. 


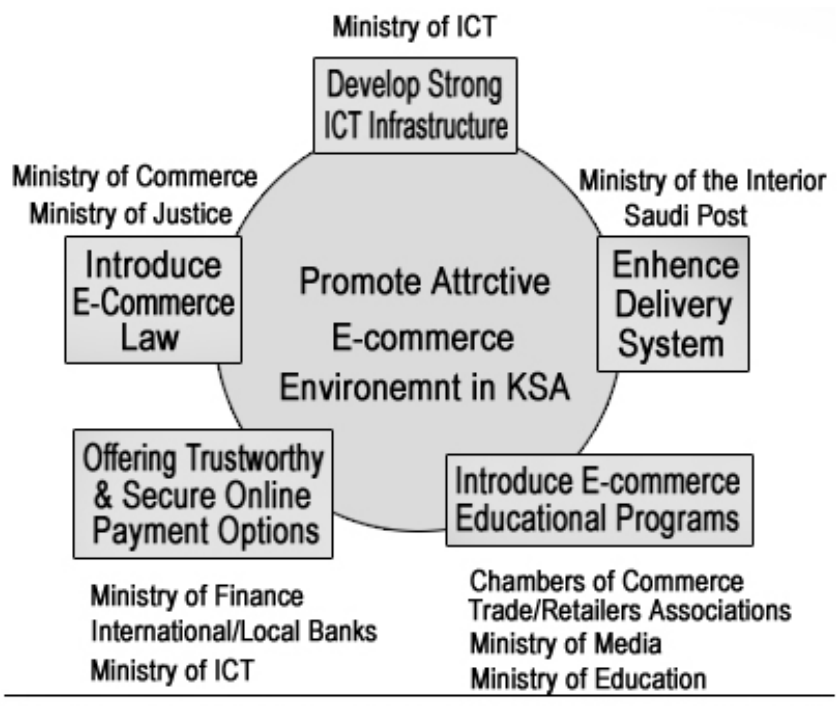

Figure 2: proposed model for the roles that Saudi government should act in order to promote the e-commerce development in the country

As yet, the Ministry of Commerce and Chambers of commerce in Saudi Arabia have no significant involvement with e-commerce. Since 2006 the responsibility of ecommerce has transferred to the Ministry of Communications and Information Technology (MCIT) to avoid overlapping. However, MCIT also currently has no significant involvement with e-commerce [15]. Data collected form Ministry of Commerce and MCIT showed there is no strategy to develop e-commerce activities in the country. It seems each government body does not understand clearly its role in this new type of business. E-commerce business is not only about running a website and selling via it. Clarifying the rules of the e-marketplace should be highly prioritized by the Ministry of Commerce. Legal and commercial framework, financial issues and intellectual property protection are all very important to be clarified. This step contributes to the building trust as well.

The Internet users increased from one million $(5 \%$ of the population) in 2001 to 11.2 million (41\%) in 2010 [30]. "Broadband subscriptions have grown from 64 thousand in 2005 to over 3.2 million at the end of Q3 2010.” [30] However, broadband subscriptions remain very low compared to the developed nations. Until 2011, the number of Internet Service Providers (ISPs) has reached only 56 [30]. However, most of the services provided by these companies are mainly from the main cities. Small cities and villages are still not well served by Internet connections or have no Internet connections at all. Prices also need to be reviewed to make it attractive for most of the households to connect to the Internet. The role of building strong Internet infrastructure is very important for the digital economy. MCIT is well placed to play active role in this regard.

Offering trustworthy and secure online payment options is a very important factor. In the West, using credit cards to pay is the most popular method to conduct online purchases. In Saudi Arabia, however, many consumers are reluctant to use credit cards, both because of a lack of trust and because some consumers are culturally averse to carrying out transactions linked with conventional interest rates. Thus, providing alternative, trustworthy and easy-to-use payment options is a critical need for the industry. Possible solutions include debit cards and payment systems such as PayPal. Another option is the electronic bill presentment and payment system which Saudi Arabia has developed for billers and payers who are resident in the country, called SADAD. In essence, the system facilitates data exchange between registered billers and the nation's commercial banks, and relies on existing banking channels (such as Internet banking, telephone banking, ATM transactions, and even counter transactions) to allow bill payers to view and pay their bills via their banks [31]. Currently, SADAD is limited to 100 billers. This means only the biggest billers in the Saudi Arabia have access to this system. "This limits most Internet merchants to using credit cards, short code SMS, and prepaid cards as electronic payment methods. To address this limitation, SADAD is currently working on Biller Base Expansion, which will increase its biller options from around 100 to 20,000" [9]. So, cooperation between all involved government and industry is needed to provide various online payment options.

Until 2005, individuals in Saudi Arabia had no home addresses [24]; therefore, to receive mail, individuals had to subscribe to have a mailbox in the post office [5]. In 2005, the postal delivery to homes and buildings was approved by Saudi Post [5, 24]. 'Wasel' is a mail service enabling Saudi residents to receive mail at their residence free of charge. Another service called "Wasel Special" has charges for sending mail from a home mailbox, delivery with e-stamp, temporary safe-keeping, temporary forwarding, P.O. Box transfer and e-mail notification. However, this service does not cover all Saudi cities, only the main ones [32]. More than half a million people subscribe to the 'Wasel' service representing almost $2 \%$ of the population who own a mailbox. While this service is still relatively new, Saudi Arabia is very late in providing individual addresses. Problems with adopting this service might be the citizens' lack of awareness of this service or the importance of mailboxes, their ignorance of the direct addresses for their houses with numbers and streets names, or their mistrust of receiving their mail in this way. Consequently, more efforts are needed to motivate and educate citizens about owning house mailboxes and help them solve the related problems.

As the awareness of e-commerce in Saudi Arabia is low compared to the developed nations, government bodies (i.e. Ministry of Media, Ministry of Education and Ministry of Higher Education) introduce the e-commerce educational programs. These educational programs are not only for people bust also for businesses. Chambers of commerce can play active role to introduce educational programs for businesses as Singapore do [33]. These programs may include provision of sample e-commerce software to trial.

\section{CONCLUSION}

This paper presented findings from a series of studies researching the diffusion and adoption of online retailing in Saudi Arabia. Not only is online retailing underdeveloped in the country but also e-commerce in general. Saudi 
government leadership to promote e-commerce development seems to be sorely missing. Accordingly new research has been conducted to provide justifications for why and how the Saudi government should be involved in the diffusion of online retailing. The main outcome of this study proposed a model indicating the key roles that Saudi government could play in order to promote the e-commerce development in the country. Various government and industry bodies could effectively cooperate in order to diffuse the online retailing in the country. The model indicated five important factors to be achieved in order to attract businesses and customers deal with this new business. These factors are: introducing ecommerce law; developing strong ICT infrastructure; offering trustworthy and secure payment systems; developing a trusted and reliable nation-wide delivery system; and, introducing e-commerce educational programs.

\section{REFERENCES}

[1] K.C. Laudon, and C.G. Traver, E-commerce: business, technology, society. 3 ed. 2007, New Jersey: Pearson Prentice Hall.

[2] E.M.Rogers, Diffusion of Innovations. Fifth ed. 2003, New York: Simon \& Schuster. 551.

[3] Saudi Ministry of Commerce, E-commerce in the kingdom: Breakthrough for the future. 2001, Riyadh.

[4] U.S. Department of Commerce. 2008, U.S. \& Foreign Commercial Service and U.S. Department of State.

[5] S. Alfuraih, E-commerce and E-commerce Fraud in Saudi Arabia: A Case Study. in 2nd International Conference on Information Security and Assurance 2008. Busan, Korea: Institute of Electrical and Electronics Engineers (IEEE)

[6] B.H.Albadr, E-commerce. Science and Technology, 2003(65): p. 1419

[7] A.M. Aladwani, Key Internet characteristics and e-commerce issues in Arab countries. Information and Management, 2003. 16(1): p. 920.

[8] CITC (Communications and Information Technology Commission), Internet Usage Study in the Kingdom of Saudi Arabia 2007, Communications and Information Technology Commission: Riyadh.

[9] CITC (Communications and Information Technology Commission), IT Report 2010 On the Internet Ecosystem in Saudi Arabia. 2010, Communications and Information Technology Commission: Riyadh.

[10] R. AlGhamdi and S. Drew. Seven Key Drivers to Online Retailing in KSA. in Proceedings of the IADIS International Conference on eSociety 2011. 2011. Avila, Spain: IADIS.

[11]R. AlGhamdi, S. Drew, and O. Alfaraj, Issues influencing Saudi customers' decisions to purchase from online retailers in the KSA: a qualitative analysis. European Journal of Scientific Research 2011. 55(4): p. 22-35.

[12]R. AlGhamdi, S. Drew, and W. Al-Ghaith, Factors Influencing Retailers in Saudi Arabia to Adoption of Online Sales Systems: a qualitative analysis. Electronic Journal of Information System in Developing Countries (EJISDC), 2011. 47(7): p. 1-23.

[13]R. AlGhamdi, A. Nguyen, J. Nguyen, and S. Drew, Factors Influencing e-commerce Adoption by Retailers in Saudi Arabia: A quantitative analysis. International Journal of Electronic Commerce Studies (IJECS), in press.

[14] R. AlGhamdi, A. Nguyen, J. Nguyen, and S. Drew, Factors influencing Saudi customers' decisions to purchase from online retailers in Saudi Arabia: a quantitative analysis in IADIS International Conference e-Commerce. 2011. Rome, Italy: IADIS

[15] R. AlGhamdi, S. Drew, and S. Alkhalaf. Government Initiatives: The Missing Key for E-commerce Growth in KSA. in ICCBS 2011 (International Conference on e-Commerce, e-Business and e-Service). 2011. Paris, France: World Academy of Science, Engineering and Technology.
[16] AMEinfo. Saudi Arabia's retail sector is undergoing a major expansion. 2008 [cited 201020 Oct]; Available from: http://www.ameinfo.com/ar-107430.html.

[17] ACG (Alpen Capital Group), GCC Retail Industry. 2009, Alpen Capital Group. p. 47.

[18] A.T. Kearney, Expanding Opportunities for Global Retailers: The 2010 A.T. Kearney Global Retail Development Index. 2010, A.T. Kearney.

[19] A. Habtoor, Vision to Employ million Saudis in the Retail Sector by 2020. 2011 [cited 201121 May]; Available from: http://www.aleqt.com/2011/03/08/article_512287.html.

[20] A. Habtoor, The retail sector: 600 thousand untapped jobs and 160 billion in the hands of foreign workers. 2011 [cited 201118 May]; Available http://www.aleqt.com/2011/01/15/article_491563.html

[21] EuroMonitor International. Retailing in Saudi Arabia. 2011 [cited $201122 \quad$ May]; $\quad$ Available from: http://www.euromonitor.com/retailing-in-saudi-arabia/report.

[22] AAG (Arab Advisor Group). Saudi Arabia's Internet users spent around US\$ 3 billion in 2010 on buying products and services through e-commerce. 2011 [cited 20111 April]; Available from: http://www.arabadvisors.com/Pressers/presser-170211.htm.

[23] A. Al-Solbi, and P.J. Mayhew, Measuring E-Readiness Assessment in Saudi Organisations Preliminary Results From A Survey Study, in From e-government to m-government, I. Kushchu and M.H. Kuscu, Editors. 2005, Mobile Government Consortium International LLC: Brighton, UK. p. 467-475.

[24] Saudi Post. Saudi Post: Establishment and Development. 2008 [cited $2009 \quad 21 \quad$ Nov]; $\quad$ Available from: http://www.sp.com.sa/Arabic/SaudiPost/aboutus/Pages/establishment anddevelopment.aspx.

[25] 25 Creswell, J.W., Mixed Methods Designs, in Educational Research: Planning, Conducting, And Evaluating Quantitative And Qualitative Research. 2008, Pearson Education: New Jersey. p. 551-575.

[26] 26 Morse, J.M., Principles of Mixed Methods and Multimethod Research, in Handbook of Mixed Methods in Social and Behavioral Research, A. Tashakkori and C. Teddlie, Editors. 2003, Sage Publications: Thousand Oaks, California. p. 189-208.

[27] Kamaruzaman, K.N., Y.M. Handrich, and F. Sullivan, e-Commerce Adoption in Malaysia: Trends, Issues and Opportunities, in ICT Strategic Review 2010/11 E-commerce for Global Reach R. Ramasamy and S. Ng, Editors. 2010, PIKOM (The National ICT Association of Malaysia): Putrajaya, Malaysia. p. 89-134.

[28] CDSI (Central Department of Statistics \& Information). Preliminary Results of General Census of Population and Housing 2010. 2010 $\begin{array}{llll}\text { [cited } 2011 & 22 & \text { May]; Available from: }\end{array}$ http://www.cdsi.gov.sa/index.php?option=com_content\&view=article $\& \mathrm{id}=88$.

[29] Alabboc, Q. Saudi Arabia established team work to reduce the number of foreign labor. 2009 [cited 201122 May]; Available from: $\mathrm{http}: / / \mathrm{www}$.arabianbusiness.com/arabic/561036.

[30] MCIT 2010 1. MCIT (Saudi Ministry of Communication and Information Technology). ICT indicators in K.S.A (Q3-2010). 2010 $\begin{array}{llllll}\text { [cited } 2011 & 1 & \text { April]; } & \text { Available from: }\end{array}$ http://www.mcit.gov.sa/english/Development/SectorIndices/.

[31] SADAD. About SADAD Payment System. 2004 [cited 201010 Oct]; Available from: http://www.sadad.com/English/SADAD+SERVICES/AboutSADAD/.

[32] Saudi Post. Production and Services. 2010 [cited 201014 Dec]; Available
http://www.sp.com.sa/English/SaudiPost/ProductsServices/Pages/Wa sell.aspx.

[33] Chan, B. and S. Al-Hawamdeh, The development of e-commerce in Singapore: The impact of government initiatives. Business process management journal, 2002. 8(3): p. 278-288. 